\title{
The EU-Turkey Visa Liberalisation Agreement: A Victim of Populist and Securitisation Practices?
}

\begin{abstract}
The negotiation process of the visa liberalisation between Turkey and the European Union came to a sudden halt in May 2016 when Turkish President Recep Tayyip Erdoğan stated that Turkey would not amend its anti-terrorism law as a precondition for the visa waiver deal. Going beyond the approach of general policy analyses, the paper draws inspiration from the postmodern or interpretive-discursive political tradition, and proposes discourse analysis, populism and securitisation theories as a theoretical background for finding an explanation to this abrupt move. As the author examines the visa liberalisation discourse in Turkey at the official level from May 2016 to April 2017, she points out how the government's framing connects with the wider securitisation discourse of the previous years and shows what makes it extremely difficult to challenge or counter the official narrative(s).
\end{abstract}

Keywords: European Union, Turkey, visa, asylum, refugee, securitisation

\section{Introduction}

The visa liberalisation process between Turkey and the European Union came to a halt in May 2016. That was the first time when Turkish President Recep Tayyip Erdoğan stated that Turkey would not amend its anti-terrorism law as a precondition for the visa waiver deal. The agreement would grant Turkish citizens to enter the Schengen zone without a visa for up to 90 days for tourism or business trips. After the migration agreement in March 2016, Ankara accelerated the pace of reforms aiming to fulfil the criteria on the visa liberalisation roadmap. This is why the president's announcement came as a surprise just two months later with yet only 5 of the 72 benchmarks fulfilled.

This paper raises the question of how the sudden stop so close to the long-awaited visa agreement can be explained. Europeanisation is probably the most dominant theoretical approach in studying the EU-Turkish relations. ${ }^{1}$ Based on this approach we can make an important observation concerning our research question: two crucial criteria for the success of conditionality are missing in the visa case, similarly to the whole EU-accession process. These two lacking preconditions are credibility on the EU's side and political will on the Turkish side. It is doubtful, whether the political leaders of the member states

\footnotetext{
For more background see Schimmelfennig, Frank - Engert, Stefan - Knobel, Heiko: Costs, Commitment and Compliance: The Impact of EU Democratic Conditionality on Latvia, Slovakia and Turkey. JCMS, Vol. 41, No. 3, 2003, pp. 495-518; Eralp, Atila: The EU Accession Process and Europeanization in Turkey. In: Turkey, Sweden and the European Union: Experiences and Expectation, Sieps, Stockholm, 2006, pp. 147-168; Alessandri, Emiliano: Democratization and Europeanization in Turkey After the September 12 Referendum. Insight Turkey, Vol. 12, No. 4, 2010, pp. 23-30; CAVLAK, Hakan - IşıK, Hayriye: The Limits of Conditionality: Turkey-EU Taxation Negotiations. International Journal of Finance \& Banking Studies, Vol. 4, No. 4, 2015, p. 29; BuHARI-Gulmez, Didem: Europeanization in a Global Context: Integrating Turkey into the World Polity. Palgrave MacMillan, 2017.
} 
would grant Turkey the visa-free travel even if Ankara meets every necessary criterion. Nevertheless, we argue that it would be worth President Erdoğan's going along with the visa liberalisation roadmap in order to put the EU in a normatively/rhetorically entrapped situation. In this regard, our real research puzzle is why there is no political will in Ankara to take at least symbolic measures toward fulfilling the remaining criteria, especially when taking into consideration that the anti-terrorism $\operatorname{law}^{2}$ has already been amended multiple times during the accession negotiations.

There are several possible answers to this question. A common argument is that Erdoğan simply does not want to let certain people flee from Turkey and this is why he is not interested in the deal. However, visa liberalisation has almost nothing to do with border control in this sense. The Turkish authorities would still be able to control who can leave the country at the border crossing points. Also, authorities can reject issuing passports to any citizen. This fact gains more importance considering that newly introduced biometric passports would be required to enter the $\mathrm{EU}$ after the deal comes into force. There is another argument, namely, that terrorism is just a cover and the real issue is the other delicate criterion on the roadmap: the requirement of a more effective fight against corruption. However, it still does not give an answer to the question why Ankara is not willing to take at least symbolic measures towards its fulfilment, like for example Ukraine did - so far without a real solution to the corruption problem. This is why we started to look for an alternative explanation.

Although there are several analyses focusing on the EU-Turkey visa issue in general, there is a lack of studies that explicitly explain why the visa negotiation process stopped at the Turkish side. Most articles introduce the background and the history of the visa negotiations. ${ }^{3}$ The possible effects and the potential security implications of the Turkish visa free access are also widely analysed. ${ }^{4}$ Relatively few studies investigate the reasons why this issue is so delicate, and even those texts attempt to answer the question why Europeans

\footnotetext{
Terrorism has no consensual international definition that has been underlined several times by the Turkish authorities. Nevertheless, the Turkish anti-terror law is long disputed by different international organisations because of its extensive definition. To take an example, 'offences against the government', more closely 'attempts to remove the Government of the Republic of Turkey from power or to prevent it from performing its duties in whole or in part' can be considered terrorist offences, together with the violation of the Constitution, supplying arms or the assassination of the President. Categories like supporter of terrorism and distributing terrorist propaganda are also very widely defined. The Turkish anti-terror law entered into force years before the Justice and Development Party (AKP) was established, so it is not the party's invention, yet this law made it possible to legally accuse plenty of people with terrorist charges during the last few years.

3 For more background see Knaus, Gerald: EU-Turkey Relations: A Visa Breakthrough?, Global Turkey in Europe Policy Brief 11, March 2014. [18.09.2017.]; ÖzLer, Zeynep: Breaking the Vicious Circle in EU-Turkey Relations: Visa Negotiations. Turkish Policy Quarterly, Vol. 11, No. 1, 2012, pp. 121-131. [18.09.2017.]; PAuL, Amanda - SeYreK, Demir Murat: EU visa-liberalisation for Turks: just around the corner? EPC Commentary, 03.05.2016. [10.09.2017.]; PEŤKová, Lenka: EU's Readmission Agreement And Visa Liberalization Talks With Turkey: Backing Up Turkey's Protracted Way To The EU, GpoT Policy Brief, No. 33, August 2012. [04.09.2017.]

4 The European Commission provides probably the best assessments regarding this topic. European Commission: Assessment of the Migratory Impact of Visa Liberalisation. In: Second Report on progress by Turkey in fulfilling the requirements of its visa liberalisation roadmap, [online], 04.03.2016a, pp. 28-46. Source: eur-lex.europa.eu [12.09.2017.]; European Commission: Assessment of the Security Impact of Visa Liberalisation. In: Third Report on progress by Turkey in fulfilling the requirements of its visa liberalization roadmap, [online], 04.05.2016b. Source: eur-lex.europa.eu [12.09.2017.]
} 
are 'afraid of' the Turks. ${ }^{5}$ Nevertheless, we argue that it is equally vital to understand the Turkish side.

In an attempt to fill this gap in the literature, the paper draws inspiration from the postmodern or interpretive-discursive political tradition, and proposes discourse analysis, populism and securitisation theories as a theoretical background. In this theoretical frame, the study analyses the discourse (selected speeches, statements, interviews) of prominent Turkish governmental actors. The reason for this limitation is that we are primarily interested in the process of how the official narratives influence people's perceptions. The official framing is getting more and more important, considering that the government's narratives on different issues have become unquestionably hegemonic, especially after last year's attempted coup. ${ }^{6}$

The paper is structured the following way. It introduces the theoretical background first. Secondly, it applies populism and securitisation theories in the context of the Turkish politics. It introduces the government's 'othering' practices and then suggests that the extensive use of the 'terrorist' label strongly contributed to the securitisation of the Turkish political environment. As a result, any opposing voice became an 'enemy' that poses an 'existential threat' to Turkey. Moreover, the paper argues that the above presented framework is useful for examining the Turkey-EU relations, as well. Populism made the EU an external 'Other', and the 'supporter of terrorists' label securitised the EU's demands mostly by evoking the so called Tanzimat and Sèvres Syndromes. Finally, the paper examines the visa liberalisation discourse in Turkey at the official level from May 2016 to April 2017. The study points out how the government's framing connects with the wider securitisation discourse of the previous years and shows what makes it extremely difficult to challenge or counter the official narrative(s).

\section{Theoretical background}

After describing the discourse analytical approach as a broader frame of our analysis, this chapter examines two important theories which play a crucial role in understanding contemporary Turkish politics and the EU-Turkey relations: populism and securitisation. Our aim is not a detailed analysis of the concepts but to give a brief introduction in order to build a common conceptual understanding and to situate our work within the literature.

What is new in our contribution from a theoretical perspective is that we combine populism and securitisation theories in an innovative way. We argue that populism and securitisation can be seen as marking two different intensity levels on a scale. The 'Manichean' distinction of populism can be raised to the level of an 'existential threat' by discursive actions. In the following chapters, we test our idea in the context of the EUTurkey visa liberalisation process.

See e.g. Baysan, Alper: Multiple Arenas and Diverse Techniques of Securitisation: The Case of the EU's Visa Regime towards Turkey. Journal of Contemporary European Research, Vol. 9, No. 5, 2013, pp. 740-758; SCHAEFER, Sarah Austin, Greg - Parker, Kate: Turks in Europe: Why are we afraid? Foreign Policy Centre, London, 2005. [01.09.2017.]

6 For further details see the 2017 report of Freedom House on Turkey. Freedom House: Freedom on the Net, Turkey, [online], 2017. Source: freedomhouse.org [05.01.2018.] 


\section{The discourse analytical approach}

As Marianne Jørgensen and Louise J. Phillips ${ }^{7}$ have pointed out, discourse analysis is not just one approach but a series of interdisciplinary approaches which stem from social constructivism and post-structuralist linguistics. Discourse analytical approaches all share the starting point that "our ways of talking do not neutrally reflect our world, identities and social relations but rather play an active role in creating and changing them". ${ }^{8}$ This viewpoint implies that there is a constant struggle at the discursive level for constructing and reproducing social reality.

Discourse analysts rely primarily on the analysis of texts as a component of discourse. Under text both the written texts and all forms of verbal products are understood. Following Norman Fairclough and Ruth Wodak, ${ }^{9}$ discourse is defined in our article as "language use in speech and writing" and is conceptualised as "a form of social practice". We also use the term narratives which are simply understood as particular interpretations of events in the paper.

Discourse analytical approaches have been used more and more frequently in the context of the EU-Turkey relations. ${ }^{10}$

\section{Populism}

Although there are numerous definitions of populism, in this paper we follow Ernesto Laclau's approach. According to Laclau, populism is not 'a type of movement - identifiable with either a special social base or a particular ideological orientation - but a political logic", ${ }^{11}$ or as he puts it "a particular mode of articulation". ${ }^{12} \mathrm{He}$ deprives the concept from its pejorative overtone and identifies populism as an inseparable part of politics. Consequently, populism becomes not a question of existence in any given political activity but a matter of extent. Laclau's approach can also explain earlier ideas found very hard to comprehend, namely how can populist parties remain populist after getting into power.

Summarising Laclau's approach, populism occurs when social space is simplified into the opposition of two antagonistic camps along with a discursively constructed frontier. Society becomes symbolically divided between 'the people' and its 'other' as a consequence of a series of politico-discursive practices. ${ }^{13}$ It is important to highlight that the identities

\footnotetext{
Jørgensen, Marianne - Phillips, Louise J.: Discourse Analysis as Theory and Method. SAGE Publications, London, 2002, p. 3 .

8 Jørgensen-Phillips (2002): op. cit. 1.

9 Wodak, Ruth - Fairclough, Norman: Critical Discourse Analysis. In: van Dijk, Teun A. (ed.): Discourse as Social Interaction. SAGE Publications, London, 1997, p. 258.

10 See e.g. Tekin, Beyza Ç.: Representations and Othering in Discourse: The construction of Turkey in the EU context. John Benjamins Pub Co., Amsterdam, 2010; Burak, Begüm: The Image of the "Undesired Citizen" in Turkey: A Comparative Critical Discourse Analysis of Hurriyet and Zaman Newspapers. The GW Post Research Paper, December 2012; HaUgE, Hanna-Lisa et al.: Mapping milestones and periods of past EU-Turkey relations. FEUTURE Working Paper, September 2016.

11 Laclau, Ernesto: On Populist Reason. Verso, London, 2005a, p. 117.

12 Laclau, Ernesto: Populism: What's in a Name? In: Panizza, Francisco (ed.): Populism and the Mirror of Democracy. Verso, London, 2005b, p. 34.

13 LaClau, Ernesto: Politics and Ideology in Marxist Theory. NLB, London, 1977.
} 
on both sides of the antagonistic frontier are political constructs rather than sociological categories. Group-construction happens along the following logic. Firstly, an equivalent chain between different unfulfilled social demands is created. Secondly, this equivalent chain has to be consolidated, which happens through the emergence of a so called 'empty signifier'. An empty signifier is not a signifier without a signified but "a signifier which becomes detached from its particular meaning in order to provide an empty space that can be filled with universal meanings". ${ }^{14}$ It functions as a point of identification for various groups of society. ${ }^{15}$ The empty signifier "gives coherence to the chain by signifying it as a totality" ${ }^{16}$

\section{Securitisation}

Following the Copenhagen School of Security Studies, securitisation is conceptualised as a speech act in which the securitising actor (mostly the political elite) states that a certain matter poses threat to the survival of the referent object (usually, but not exclusively the state/society). ${ }^{17}$ From this point of view it is irrelevant whether something is objectively threatening or not. The urgency and the existential nature of the presented threat legitimise the use of extraordinary measures and the breaking of normal (democratic) rules. Costs do not matter and there is almost no debate over the government's measures since it is about the neutralisation of the threat or what the government declares to be a threat. Another politically beneficial feature of these security situations is that they usually increase the popularity of the governing parties, almost independently from their real performance. An average citizen in every modern society gains their knowledge of security through mass media and political discourse. Therefore, their perception of security is not based on direct experience. As a result of this, finding acceptance among the members of the audience for the securitisation of any issue is not very difficult. ${ }^{18}$

\section{Populism and securitisation as main characteristics of the Turkish politics - Introducing the context}

\section{Populism in Turkey during the AKP era (2002-2017)}

Based on populism theory we can state that the key factor behind the Justice and Development Party's (AKP) success ${ }^{19}$ in its early years was twofold. First, the party managed

\footnotetext{
Wullweber, Joscha: Global politics and empty signifiers: the political construction of high technology. Critical Policy Studies, Vol. 9, No. 1, 2014, p. 82.

15 Thomassen, Lasse: Hegemony, populism and democracy: Laclau and Mouffe today. Revista Española de Ciencia Política, No. 40, March 2016, p. 166. [20.09.2017.]

16 Laclau (2005b): op. cit. 44.

17 Buzan, Barry - Wæver, Ole - Wilde, Jaap de: Security: A New Framework for Analysis. Routledge, London, 1998.

18 TÁlas, Péter: A terrorveszélyhelyzet-diskurzus margójára. Nemzet és Biztonság, Vol. 9, No. 1, 2016, p. 41.

19 Since 2002, the AKP has gained absolute majority in every parliamentary election. It is important to highlight that the fairness of the elections between 2002 and 2015 has not been questioned either by the Turkish opposition or by international monitoring groups.
} 
to unite different social demands under the empty signifier 'Muslim democracy'. Second, it successfully identified the Kemalist elite as the opponent of the newly constructed 'people'.

Anti-elitist feelings are deep-rooted in the majority of the Turks. After the death of Mustafa Kemal Atatürk, the Turkish Armed Forces (TAF) stepped up as the guardian of the newly established secular state. In the following decades, the Kemalist regime was sustained by force, failing to gain the support of the majority of the people. Therefore, the AKP did not have to try too hard to construct the image of the 'Other'.

Based on historical experience, a coup by the TAF or the closure of the party by the Constitutional Court was a possible scenario all along, given the AKP's Islamist roots. For this reason, after gaining enough confidence by the landslide victory on its second parliamentary elections, the AKP started to eliminate its Kemalist opponents in the name of 'the people'. Ergenekon and Balyoz trials were the two most emblematic cases. 'Advanced democracy' has emerged as a new empty signifier in 2007, which showed the newly gained confidence of the party.

As Başak Alpan highlights, 'national will' has moved to the forefront of the AKP's rhetoric during these years. ${ }^{20}$ In 2008 a closure trial started against the AKP at the Constitutional Court. Erdoğan evaluated this trial as "an attack not on the AKP as such, but on the national will". ${ }^{21}$ The AKP's understanding of democracy can be observed regarding these events. Every attack on the AKP has been considered as an attack against the Turkish nation. This is the very feature of populism: one part of the society identifies itself as 'the whole. With Laclau's words, the 'plebs' is claiming to be identical with the 'populus'. The understanding of democracy was narrowed further after the election of Erdoğan from prime minister to president in 2014. Every critique of Erdoğan was taken as an attack against democracy, since according to the government's approach the leader embodies the nation's interest. One indicator of this tendency is the number of trials initiated because of the 'insult' of the president and which number increased from 132 in 2014 to 1,953 in 2015. ${ }^{22}$

Checks and balances were removed from the Turkish political system also by referring to the 'national will. Erdoğan presented these mechanisms as "the last vestiges of tutelage on popular will". According to this reasoning, an independent judiciary, for example, which is not controlled by 'national will' could prevent the fulfilment of the nation's interests and that is why it is necessary to take measures to subordinate this institution. ${ }^{23}$

After annihilating the threat posed by the Kemalists, the government turned toward the sole remaining rival power centre: the Hizmet movement. Since the antagonistic frontier between 'the people' and 'the Other' is discursively constructed, it can be easily displaced. The former AKP ally Fethullah Gülen and his followers were accused of attempting a 'judicial coup' against the legitimately elected government by initiating corruption investigations and supporting the Gezi protests in 2013. Although the reason

20 Alpan, Başak: From AKP's 'Conservative Democracy' to 'Advanced Democracy': Shifts and Challenges in the Debate on 'Europe'. South European Society and Politics, Vol. 21, No. 1, 2016, p. 20.

${ }^{21}$ CNN Türk: "Millet iradesi hiçe sayılamaz", [online], 15.03.2008. Source: cnnturk.com [20.09.2017.]

22 ECHR: European Court of Human Rights Judgment in the Case of Artun and Güvener v. Turkey, [online], 2016. Source: aihmiz.org.tr [12.09.2017.]

23 KAYNAK, Akif Bahadır: Rise of Neo-Populism and the Decline of European Agenda in Turkey. BUJSS, Vol. 9, No. 1. 2016, p. 182. 
behind the clash was merely power political in nature, Erdoğan made it look like Hizmet directly attacked the Turkish nation. The reconstruction of 'the people' happened along with the empty signifier of 'New Turkey'.

\section{Securitisation through the 'terrorist' label}

Turkey indisputably suffered a lot from terrorism in 2015-2016. According to the Global Terrorism Database, 490 people died in 421 incidents in 2015, and 1,004 died in 540 incidents in $2016,{ }^{24}$ making it one of Turkey's deadliest years. However, after comparing the data with the numbers of those who have been dismissed from their workplaces $(146,674)$ and have been arrested $(59,254)$ in the post-coup purge, one has the feeling that these measures are about something else than solely preventing terrorist attacks. ${ }^{25}$

The AKP took advantage of the country's facing a major crisis since in time of a terrorist attack every citizen turns to the government in power for defence and support and expects the executive to solve it. In June 2015, the AKP faced the possibility of losing the absolute majority in the parliament the first time in the party's history. Therefore, new-old ways had to be found to remain in power. ${ }^{26}$

Hence, terrorism was made a central element of the government's discourse from 2015. As a first step, the government's rhetoric exaggerated the terror threat. A dichotomy was set up between chaos and stability where the AKP with absolute majority represents stability and any other possibility leads to chaos, threatening the very survival of the state. The message of the AKP's campaign was clear: only the AKP's majority and a presidential system led by Erdoğan can guarantee stability and can fight effectively against terrorism.

As a second step, terrorism was made an empty signifier which helped in securitising the 'Other'. Through the extensive use of the 'terrorist' label, every opponent became an enemy that posed an existential threat to the survival of the Turkish nation. Consequently, extraordinary means against them gained legitimacy.

Linking terrorism with populism and exaggerating the threat it poses have given a powerful tool to the Turkish Government. Furthermore, it strongly contributed to terrorism being the number one security threat in the eyes of the Turkish public. ${ }^{27}$ The 'terrorist' signifier was built into the populist frontier. In this new setting there is 'we' on the one side and 'they', that refers to the terrorists, as well as the supporters of terrorists, on the other side. The 'Other' is not solely someone who opposes 'the popular will' anymore but a threat to the nation's survival.

24 Data includes the fatalities of the July 2016 coup attempt.

Source of data: https://turkeypurge.com [28.09.2017.]

26 About securitisation in the EU-Turkish context see more from NoI, Aylin Ünver: Securitization's impacts on the democratization process in Turkey. In: NoI, Aylin Ünver - Toperich, Sasha (eds.): Challenges of Democracy in the European Union and Its Neighbors, Center for Transatlantic Relations, 2016, pp. 45-73. [18.09.2017.]; AçıKmeşE, Sinem Akgül: EU Conditionality and De-securitization Nexus in Turkey. Southeast European and Black Sea Studies, Vol. 13, No. 3, 2013, pp. 303-323.

$27 \quad 13.9 \%$ of the respondents saw terrorism Turkey's biggest problem in 2014 and $39.3 \%$ in 2015. Kadir Has Üniversitesi: Türkiye Sosyal-Siyasal Eğilimler Araştırması, [online], 2016. Source: khas.edu.tr [13.09.2017.] In 2016, FETÖ stepped up to the second place from $1.3 \%$ to $25.2 \%$. Kadir Has Üniversitesi: Türkiye Sosyal-Siyasal Eğilimler Araştırması, [online], 2017. Source: khas.edu.tr [13.09.2017.] 
The example of the Gülen movement illustrates the mentioned two-step process very well. In 2013, from being a friend Hizmet became the most important internal 'Other'. Later, in October 2015, Fethullah Gülen was already listed as one of the most-wanted terrorists. On 31 May 2016 (six weeks before the July coup attempt), Hizmet was renamed to Fethullah Terror Organisation (FETÖ) and officially considered a terrorist organisation by the Turkish authorities. The July 2016 coup attempt speeded up the above described process, thus we do not consider it a turning point. FETÖ was immediately accused of the coup. The official discourse simplified the political space into a plain dichotomy: there are those who have been supporting the coup ('terrorists') and those who are against it ('the people').

The authoritarian character of the current Turkish political regime and the control it exercises over the media prevent any alternative explanation on terrorism. In February 2017, Erdoğan took one more step towards monopolising the interpretation of terrorism. A new measure was introduced by the Supreme Council of Radio and Television (RTÜK) which strictly limited the broadcasting on terrorist attacks, making the government's hegemony persistent in the discursive field. ${ }^{28}$

\section{The EU as an external 'Other' and an 'existential threat'?}

The above described process of enemy construction through populist and securitisation discourse can be applied to construct external 'Others' and threats. As Senem-Aydin Düzgit demonstrates in her analysis, between 2011-2015, the EU was mainly represented in the AKP's discourse as "an unwanted intruder in Turkish politics", "an essentially discriminatory entity" and "inferior" to Turkey on political and economic (and sometimes normative) grounds. ${ }^{29}$ We claim that after 2015, mostly by the frequent use of the supporter of terrorists' label, the image of a direct threat complemented the notion of the 'Other'. A recent survey of the Kadir Has University ${ }^{30}$ shows the success of the government's rhetoric: in 2017, Turks perceived the EU as the third biggest threat to Turkey after the United States and Israel, overtaking the place of Russia and Armenia. The EU's perception as a threat increased more than $100 \%$ from 2016 , which is striking.

We argue that using positive or negative narratives regarding the EU and certain member states is a strategic choice of the Turkish Government which is largely internally driven. The EU was mobilised as a normative political context from time to time in order to satisfy internal political demands. ${ }^{31}$ To put it another way, the EU was used to help the empty signifiers operate. ${ }^{32}$ The EU was an essential legitimatisation tool for the AKP vis-a-vis the Kemalists, in the early years of its ruling. The party was able to limit the armed forces'

28 Hürriyet Daily News: Turkey's TV watchdog introduces new measures limiting terror attacks broadcasting, [online], 02.02.2017. Source: hurriyetdailynews.com [12.09.2017.]

29 Aydin-Düzgit, Senem: De-Europeanisation through Discourse: A Critical Discourse Analysis of AKP's Election Speeches. South European Society and Politics, Vol. 21, No. 1, 2016, pp. 45-58.

30 Kadir Has Üniversitesi: Türkiye Sosyal-Siyasal... (2017).

31 The definition of Europeanisation as a normative political context comes from Alper Kaliber. KALIBER, Alper: Contextual and Contested: Reassessing Europeanization in the Case of Turkey. International Relations, Vol. 27, No. 1, 2012, pp. 52-73. [13.09.2017.]

32 Alpan (2016): op. cit. 18. 
power and prevent a coup through referring to the reforms requested by the EU. However, the EU soon became the main source of external critique and one of the most important external 'Others'. Two parallel developments played a significant role in this change: on the one hand, the increasing self-confidence of the AKP and the decreasing credibility of the EU on the other. These two factors together led to the slowdown of the Turkish-EU accession process.

It is important to note that the negative portrayal of the EU does not exist in a vacuum: a strong interdiscursivity can be identified "between Erdoğan's discourse and some of the widely established discourses on the EU across Turkish society, which makes Erdoğan's discourse resonate across the broader public" ${ }^{33}$ In our article we only refer to the so-called Tanzimat and Sèvres Syndromes. According to the propagators of these ideas, Europe has had a hidden agenda since the time of the Crusaders which aims to drive the Turks out of Anatolia. The two 'syndromes' represent the embedded fear of Turks that Western powers' real intention is to weaken and divide Turkey. They would do that in two ways: either from the inside or from the outside. Tanzimat Syndrome suggests that the EU demands more rights for the minorities living in Turkey because it wants their secession. According to the Sèvres Syndrome, the Europeans want to divide Turkey up among themselves, like it was envisaged in the Treaty of Sèvres in 1920.

The consistent use of negative narratives on the EU gives the Turkish Government not just more power in general but one more legitimising argument why not to take further steps on the visa liberalisation roadmap. If we accept the strategic character of this usage, we can come to the following conclusion: Erdoğan may think that keeping the conflict-based message on the EU coherent can give him more supporters at the domestic political level than breaking it with cooperation and reforms. The next chapter's case study shows several examples of how populist and securitisation techniques work in the context of the visa liberalisation negotiation.

\section{The official Turkish discourse on the EU-Turkey visa liberalisation negotiation}

We chose ten texts ( 5 political speeches, 2 parliamentary speeches, 3 transcripts of press conferences) from Turkish governmental actors (6 from President Recep Tayyip Erdoğan, 2 from Presidential Spokesperson İbrahim Kalın, 1 from former Minister of European Union Affairs Volkan Bozkır, 1 from Minister of European Union Affairs Ömer Çelik) about the EU and the visa issue so that we can shed a light on how the articulatory processes of including and excluding meaning take place. The reason of the predominance of the presidency's speeches among the selected texts is that according to our view, the president's word is decisive in the current Turkish political setting. We analyse the events that took place from 6 May 2016 to 16 April 2017. The former is the date when President

33 Aydin-Düzgit (2016): op. cit. 56. 
Erdoğan announced not amending the anti-terrorism law and the latter is the date of the Turkish constitutional referendum on the presidential system. It is important to highlight that the examined, approximately one-year period is in the run-up to the referendum and therefore the campaign was a major driver behind the harsh rhetoric. Our intention in the selection of the texts was to include all major arguments regarding the topic. The list of the analysed texts can be found at the end of the study; we solely specify our results in this chapter of the article.

The following claims were identified in the argumentation structure of the selected texts:

Claim 1: Turkey has fulfilled the criteria on the visa roadmap. It is the EU's turn.

Claim 2: Turkey should have been included in the Schengen Visa System much earlier. It is a grave shortcoming of the EU that Turkey has not been included.

Claim 3: Turkey definitely wishes a resolution to the visa issue and wants its citizens to be included in the Schengen Visa System.

Claim 4: The EU does not want to keep its promises made to Turkey. The EU is not open, transparent or sincere.

Claim 5: Exclusionist discourses (discrimination, cultural racism, xenophobia and Islamophobia) became widespread across the continent, which is poisoning the Turkey-EU relations and threatening Europe's future.

Claim 6: Any amendment on the anti-terror law is not a possible scenario. The EU should not request anything that may compromise or diminish the capacity of Turkey's fight against terror.

Claim 7: The EU has no authority to decide in the internal matters of Turkey.

Claim 8: The EU does not see Turkey's realities.

Claim 9: The EU does not stand beside Turkey in the fight against terror.

Claim 10: The EU finds it unacceptable that Turkey would fight terrorism.

Claim 11: The EU directly or indirectly supports terrorist organisations and anti-Turkey formations with the aim of weakening Turkey, as it was its purpose earlier in history.

Claim 12: The security of Turkey is inseparable from the security of Europe. Therefore, the $\mathrm{EU}$ is also interested in the effective Turkish fight against terrorism.

Claim 13: In the upcoming period Turkey will either continue dealing with the EU or it will set a new path for itself. Ankara will possibly announce a referendum on the continuation of the EU accession process.

Claim 14: Turkey will break the migration deal with the EU if visa-free travel is not granted to the Turks soon.

The discourse on the visa negotiation constructs not only the knowledge about Turkey, the EU and the criteria for the visa-free travel but also the relationship between Turkey and 
the EU along with the Turkish and European identity at the same time. ${ }^{34}$ The analysed texts describe the visa negotiations as a process in which all responsibilities lie with the EU. The Turkish Government is not responsible for any shortcomings; Turkey sufficiently fulfilled the required criteria. As for the characteristics of the relationship, the texts show that the EU applies double standards and does not consider Turkey as an 'equal' partner. Yet, Turkey can stand without the EU, if it continues this 'discriminatory' and 'insincere' attitude. The EU is presented only negatively, and Turkey is presented only positively in the texts, which serve as the basis of the othering process described earlier. We have not found any exceptions to that in the examined period. The EU appears as an actor which does not want to keep its promises, constantly raises obstacles, is hypocrite, shows no solidarity and its approach is incompatible with the European values. These nominators question and make the very principles of the European identity uncertain. In contrast, Turkey is portrayed as a country which wants to cooperate, has been waiting for the decision of its 'European friends', is heroically struggling against terrorism, has been simultaneously defending Europe, and can find new, independent ways for itself whenever it decides to do so.

Concerning our analytical focus, every claim can be classified as either a populist action $(1,2,3,4,7,9)$ or a securitisation attempt $(6,10,11,12,14)$ or simultaneously both $(5,8,13)$. The estrangement of the EU was taken to the level of an 'existential threat' by using the 'terrorist' label. According to the analysed texts the EU allows terrorists to put up tents close to the European Parliament, finds unacceptable for Turkey to fight against terrorism, and even finances terrorists. The accusations resonate well with the Tanzimat and Sèvres Syndromes. It should be noted that not only the EU's securitisation has been attempted in the process. With the same rhetorical actions, Turkey can also make itself securitised in the eyes of the Europeans, primarily through referring to the migration issue $(12,14)$.

\section{Conclusions}

The paper examined why there is no political will on the Turkish side toward fulfilling the criteria on the EU-Turkey visa liberalisation roadmap. Based on the proposed theories and methodology, two main reasons were identified. Firstly, terrorism has become a too central element of the governmental discourse. Secondly, the Turkish Government finds the negative rhetoric on the EU profitable in terms of votes. The visa liberalisation deal is on the one hand a victim of the populist and securitisation techniques but on the other, it is used as a tool in reconstructing and strengthening the wider populist and securitisation discourse. The EU gives a context to the Turkish political infighting, which context can be discursively mobilised to strengthen the government's position. So that the internal power games have a strong influence on the EU-Turkey relations, as well.

\footnotetext{
4 HüLsse, Rainer: The Discursive Construction of Identity and Difference - Turkey as Europe's Other? Discussion paper presented at the ECPR Joint Sessions of Workshops, Mannheim, 26-31 March, 1999, [online], 2000, p. 16. Source: ecpr. eu [05.01.2018.] Based on Michael Halliday's work (1973) Norman Fairclough identifies three functions of language: ideational, relational and identity functions. Fairclough, Norman: Critical Discourse Analysis: The Critical Study of Language. Longman, London, 1995, p. 131.
} 
Challenging or countering the official narratives is extremely difficult due to at least three reasons. First, the government has an unquestionably hegemonic position in the discursive field in Turkey. Second, the government's framing resonates well with both the earlier negative narratives on the EU and the wider securitisation discourse of the previous years. It helps the public internalise the official narrative on the visa issue. Finally, probably the biggest challenge is that every de-securitisation attempt or even every critique of the government, by either internal or external actors, can be translated within this well-built discursive frame into a direct threat to Turkey as a whole, thus pictured as an existential threat. As a consequence, there is a paradox situation where the EU gets securitised right through its de-securitisation attempts. The only question seems remaining is whether Erdoğan is determined to continue this practice to the 2019 parliamentary and presidential elections in order to keep the $51 \%$ of the votes together and ignores the damages he causes.

\section{REFERENCES}

AçıкmEşE, Sinem Akgül: EU Conditionality and De-securitization Nexus in Turkey. Southeast European and Black Sea Studies, Vol. 13, No. 3, 2013, pp. 303-323. DOI: https://doi.org/10.1080/14683857.2013.812772

Alessandri, Emiliano: Democratization and Europeanization in Turkey After the September 12 Referendum. Insight Turkey, Vol. 12, No. 4, 2012, pp. 23-30.

Alpan, Başak: From AKP's 'Conservative Democracy' to 'Advanced Democracy': Shifts and Challenges in the Debate on 'Europe.' South European Society and Politics, Vol. 21, No. 1, 2016, pp. 15-28. DOI: https://doi. org/10.1080/13608746.2016.1155283

Aydin-Düzgit, Senem: De-Europeanisation through Discourse: A Critical Discourse Analysis of AKP's Election Speeches. South European Society and Politics, Vol. 21, No. 1, 2016, pp. 45-58. DOI: https://doi.org/10.108 0/13608746.2016.1147717

Baysan, Alper: Multiple Arenas and Diverse Techniques of Securitisation: The Case of the EU's Visa Regime towards Turkey. Journal of Contemporary European Research, Vol. 9, No. 5, 2013, pp. 740-758.

Börzel, Tanja A. - Soyaltin, Digdem: Europeanization in Turkey. Stretching a Concepttoits Limits? KollegForschergruppe Working Paper Series, 2012/36.

Buhari-Gulmez, Didem: Europeanization in a Global Context: Integrating Turkey into the World Polity. Palgrave MacMillan, 2017. DOI: https://doi.org/10.1057/978-1-349-95059-1

Burak, Begüm: The Image of the "Undesired Citizen" in Turkey: A Comparative Critical Discourse Analysis of Hurriyet and Zaman Newspapers. The GW Post Research Paper, December 2012.

BuZAN, Barry - WÆVER, Ole - WILDE, Jaap de: Security: A New Framework for Analysis. Routledge, London, 1998.

CAVLAK, Hakan - Işı, Hayriye: The Limits of Conditionality: Turkey-EU Taxation Negotiations. International Journal of Finance \& Banking Studies, Vol. 4, No. 4, 2015, pp. 29-43. DOI: https://doi.org/10.20525/ijfbs.v4i4.38

CNN Türk: "Millet iradesi hiçe sayllamaz", [online], 15.03.2008. Source: cnnturk.com [20.09.2017.]

ECHR: European Court of Human Rights Judgment in the Case of Artun and Güvener v. Turkey, [online], 2016. Source: aihmiz.org.tr [12.09.2017.]

Eralp, Atila: The EU Accession Process and Europeanization in Turkey. In: Turkey, Sweden and the European Union: Experiences and Expectations. Sieps, Stockholm, 2006, pp. 147-168.

European Commission: Roadmap towards a Visa-Free Regime with Turkey, [online], 16.12.2013. Source: ec.europa.eu [12.09.2017.]

European Commission: Assessment of the Migratory Impact of Visa Liberalisation. In: Second Report on progress by Turkey in fulfilling the requirements of its visa liberalisation roadmap, [online], 04.03.2016a, 28-46. Source: eur-lex.europa.eu [12.09.2017.] 
European Commission: Assessment of the Security Impact of Visa Liberalisation. In: Third Report on progress by Turkey in fulfilling the requirements of its visa liberalization roadmap, [online], 04.05.2016b. Source: eur-lex. europa.eu [12.09.2017.]

FaIrClough, Norman: Critical Discourse Analysis: The Critical Study of Language. Longman, London, 1995.

Freedom House: Freedom on the Net, Turkey, [online], 2017. Source: freedomhouse.org [05.01.2018.]

HallidaY, Michael A. K.: Explorations in the Functions of Language. Edward Arnold, London, 1973. DOI: https:// doi.org/10.1017/S0008413100008203

Hauge, Hanna-Lisa - Eralp, Atila - Wessels, Wolfgang - Bedir, Nurdan Selay: Mapping milestones and periods of past EU-Turkey relations. FEUTURE Working Paper, September 2016.

HÜLSSE, Rainer: The Discursive Construction of Identity and Difference - Turkey as Europe's Other? Discussion paper presented at the ECPR Joint Sessions of Workshops, Mannheim, 26-31 March, 1999, [online], 2000. Source: ecpr.eu [05.01.2018.]

Hürriyet Daily News: Turkey's TV watchdog introduces new measures limiting terror attacks broadcasting, [online], 02.02.2017. Source: hurriyetdailynews.com [12.09.2017.]

Jørgensen, Marianne - Phillips, Louise J.: Discourse Analysis as Theory and Method. SAGE Publications, London, 2002. DOI: https://doi.org/10.4135/9781849208871

Kadir Has Üniversitesi: Türkiye Sosyal-Siyasal Eğilimler Araştırması, [online], 2016. Source: khas.edu.tr [13.09.2017.]

Kadir Has Üniversitesi: Türkiye Sosyal-Siyasal Eğilimler Araştırması, [online], 2017. Source: khas.edu.tr [13.09.2017.]

KALIBER, Alper: Contextual and Contested: Reassessing Europeanization in the Case of Turkey. International Relations, Vol. 27, No. 1, 2012, pp. 52-73. [13.09.2017.] DOI: https://doi.org/10.1177/0047117812455352

KAYNAK, Akif Bahadır: Rise of Neo-Populism and the Decline of European Agenda in Turkey. BUJSS, Vol. 9, No. 1, 2016, pp. 173-186. DOI: https://doi.org/10.18221/bujss.59860

Knaus, Gerald: EU-Turkey Relations: A Visa Breakthrough? Global Turkey in Europe Policy Brief 11, March 2014. [18.09.2017.]

LaClau, Ernesto: Politics and Ideology in Marxist Theory. NLB, London, 1977.

LACLAU, Ernesto: On Populist Reason. Verso, London, 2005a.

Laclau, Ernesto: Populism: What's in a Name? In: Panizza, Francisco (ed.): Populism and the Mirror of Democracy. Verso, London, 2005b, pp. 32-50.

Müftüler-BAÇ, Meltem - TaşKin, Evrim: Turkey's Accession to the European Union: Does Culture and Identity Play a Role? Ankara Review of European Studies, Vol. 6, No. 2, 2007, pp. 31-50. DOI: https://doi. org/10.1501/avraras_0000000107

NAs, Çiğdem - Özer, Yonca (eds.): Turkey and the European Union: Processes of Europeanisation. Farnham, Ashgate, 2002.

NoI, Aylin Ünver: Securitization's impacts on the democratization process in Turkey. In: NoI, Aylin Ünver - ToperICH, Sasha (eds.): Challenges of Democracy in the European Union and Its Neighbors. Center for Transatlantic Relations, 2016, pp. 45-73. [18.09.2017.]

ÖzLER, Zeynep: Breaking the Vicious Circle in EU-Turkey Relations: Visa Negotiations. Turkish Policy Quarterly, Vol. 11, No. 1, 2012, pp. 121-131. [18.09.2017.]

PAUL, Amanda - SEYREK, Demir Murat: EU visa-liberalisation for Turks: just around the corner? EPC Commentary, 03.05.2016. [10.09.2017.]

PeŤKovÁ, Lenka: EU's Readmission Agreement And Visa Liberalization Talks With Turkey: Backing Up Turkey's Protracted Way To The EU. GpoT Policy Brief, No. 33, August 2012. [04.09.2017.]

Rumelili, Bahar: Negotiating Europe: EU-Turkey Relations from an Identity Perspective. Insight Turkey, Vol. 10, No. 1,2008 , pp. 97-110.

Schaefer, Sarah - Austin, Greg - PArker, Kate: Turks in Europe: Why are we afraid? Foreign Policy Centre, London, 2005. [01.09.2017.]

Schimmelfennig, Frank - Engert, Stefan - Knobel, Heiko: Costs, Commitment and Compliance: The Impact of EU Democratic Conditionality on Latvia, Slovakia and Turkey. JCMS, Vol. 41, No. 3, 2003, pp. 495-518. DOI: https://doi.org/10.1111/1468-5965.00432

TÁlas, Péter: A terrorveszélyhelyzet-diskurzus margójára. Nemzet és Biztonság, Vol. 9, No. 1, 2016, pp. 40-47. [11.09.2017.] 
Tekin, Ali - GüNey, Aylin: The Europeanization of Turkey. Polity and Politics. Routledge, London, 2015. DOI: https://doi.org/10.4324/9781315733128

Tekin, Beyza Ç.: Representations and Othering in Discourse: The construction of Turkey in the EU context. John Benjamins Pub Co., Amsterdam, 2010. DOI: https://doi.org/10.1075/dapsac.39

Thomassen, Lasse: Hegemony, populism and democracy: Laclau and Mouffe today. Revista Española de Ciencia Política, No. 40, March 2016, pp. 161-176. [20.09.2017.]

United States Department of State: Country Reports on Human Rights Practices for 2014, Turkey, [online], 25.06.2015. Source: state.gov [07.09.2017.]

Wodak, Ruth - Fairclough, Norman: Critical Discourse Analysis. In: van Dijk, Teun A. (ed.): Discourse as Social Interaction. SAGE Publications, London, 1997, pp. 258-284.

Wullweber, Joscha: Global politics and empty signifiers: the political construction of high technology. Critical Policy Studies, Vol. 9, No. 1, 2014, pp. 78-96. DOI: https://doi.org/10.1080/19460171.2014.918899

YILMAZ, Hakan: Two pillars of nationalist Euroskepticism in Turkey: The Tanzimat and Sevres syndromes. In: Karlsson, Ingmar - Melin, Annika Strom eds.: Turkey, Sweden and the European Union: Experiences and expectations. Swedish Institute for European Policy Studies, Stockholm, 2006, pp. 29-40.

\section{The ten selected speeches on the visa issue}

“Avrupa Birliği Tutumunu ve Tutarlılığını Sorgulamalıdır”, [online], 24.06.2016. Source: tcbb.gov.tr [01.09.2017.] Erdoğan: Er ya da geç bu milletin önüne başkanlık sistemi gelecek!, [online], 12.05.2016. Source: t24.com [01.09.2017.]

Erdoğan’ın sözleri Akar’ı duygulandırdı, [online], 07.06.2016. Source: aksam.com.tr [01.09.2017.]

Erdogan says Turkey will not change anti-terror law for sake of visa deal, [online], 06.05.2016. Source: guardian.ng [01.09.2017.]

"Europe Closes Its Doors to Yea-Sayers While Opening Them to Those Who Propagate in Favor of No", [online], 16.03.2017. Source: tcbb.gov.tr [01.09.2017.]

Statement by Presidential Spokesperson Ambassador İbrahim Kalın, [online], 18.05.2016. Source: tcbb.gov.tr [01.09.2017.]

Statement by Presidential Spokesperson Ambassador İbrahim Kalın, [online], 08.06.2016. Source: tcbb.gov.tr [01.09.2017.]

Turkey says it fulfilled refugee deal criteria, won't amend terror laws, [online], 11.05.2016. Source: dw.com [01.09.2017.]

Türkiye Büyük Millet Meclisi, Genel Kurul Tutanağı, 26. Dönem 2. Yasama Yılı, 1. Birleşim 01 Ekim 2016 Cumartesi, Recep Tayyip Erdoğan’s opening speech, [online], 01.09.2016. Source: tbmm.gov.tr [01.09.2017.]

Türkiye Büyük Millet Meclisi, Genel Kurul Tutanağı, 26. Dönem 2. Yasama Yılı, 38. Birleşim 12 Aralık 2016 Pazartesi, Ömer Celiks' answer, [online], 12.12.2016. Source: tbmm.gov.tr [01.09.2017.] 